\title{
um concerto para muitas vozes / e uma resenha a quatro mãos / em diálog̣o \\ RESENHA DE CANÇÃO DE AMOR PARA JOÃO GILBERTO NOLL (2019), DE LUIS ALBERTO BRANDÃO
}

\section{Juliana Caldas ${ }^{1}$}

\section{Thiago H. Fernandes ${ }^{2}$}

[Nota de abertura: esta resenha é antes um diálogo entre os editoresleitores-autores que a partir da repercussão do livro de Luis Alberto Brandão em suas subjetividades encontraram formas particulares de dizer sobre o livro. Inspirados pelo procedimento de cena aberta e in progress de Canção, decidiram apagar as marcas de autoria e embaralhar suas vozes resultando em uma resenha-conversa encenada no texto que segue]

$*$

Uma canção é um som. Antes mesmo de ser texto, ela é a emissão de algo que se pode ouvir e encantar. Canção de amor para João Gilberto Noll, de Luis Alberto Brandão, editado pela Relicário Edições em 2019, evoca essa forma entre a música e a literatura, que transborda o suporte do livro e das letras impressas no papel para ocupar uma espécie de concha acústica em que o texto performa e reatualiza a voz de João Gilberto Noll e daqueles que com ele ou a partir dele entoam suas próprias partituras para o encontro.

1 Professora, artista-pesquisadora e editora, atualmente, é doutoranda em Literatura brasileira pela Universidade de São Paulo com tese sobre a performatividade na poesia contemporânea. No mestrado pesquisou as relações entre artes plásticas e literatura a partir de um diálogo entre Hilda Hilst e Lygia Clark. E-mail: jubscaldas@gmail.com.

2 Professor assistente de literatura na Universidade estadual do Piauí (UESPI). Mestre e doutorando em Literatura brasileira pela Universidade de São Paulo. E-mail: thiagohfernandesp@ gmail.com. 
Caberia perguntar: do que se fala então quando se trata do livro de Brandão? A pergunta ressoa o apontamento de seu proponente, ou seja, de a publicação constar num todo a que se atribui uma noção expandida de obra (2019, p. 213). É na seção de nome "Interlúdio" que Brandão nos situa nesta narrativa maior que transcende a matéria do livro editado; aparente ponta final de um projeto que, situado na instância acadêmica, se desdobrou enquanto ideia e simultaneamente enquanto práticas no espaço público e extra universitário. Diz-se aparente ponto final, pois, a interrogação que marca esta resenha pode ser entendida ainda como uma reverberação contida nesse arco expandido da obra resenhada.

$*$

Como um livro para ser tocado - em seu duplo sentido: ouvido e tateado -, Canção de amor para João Gilberto Noll é dividido em nove seções, sendo a segunda, "Participações especiais", a mais extensa e na qual Brandão parece trazer à cena um concerto de recortes, vozes e enquadramentos que montam um Noll multidimensional e multissensorial, posto que inapreensível numa perspectiva única, bidimensional ou definitiva. Transitam nesse palco com o escritor gaúcho autores-performers como Sérgio Sant'Anna, Luci Collin, Julia Panadés, Tarso de Melo, Ana Martins Marques, Ricardo Aleixo, Bruna Kalil Othero, entre outros, que, além de construírem o imaginário deles em torno de João Gilberto Noll, configuramse também corpos em cena no movimento da literatura brasileira contemporânea. Ou seja, a participação de cada um deles no livro compõe duetos particulares como resultados de um encontro peculiar e exclusivo.

Em desfile de gêneros e textualidades, texturas e sonoridades, a Canção se apresenta sob o estilo de crônica, diário, conto, poesia, roteiro cinematográfico, cena de performance, fotomontagem, e-mail, conferência, memorial, entrevista etc., dando-nos o tom de que, se há muitas maneiras para falar de Noll, nenhuma delas sozinha é suficiente para abarcar sua face prismática e sua vida de escritor como "sujeito que está à procura" 
(2019, p. 196). Não à toa, a certa altura, mais para o final do concerto de Canção, Luis Alberto Brandão revela justamente que ela

[...] venha sendo experimentada como obra em transformação, como um ritual livre, um jogo em que as regras podem ser negociadas entre os jogadores, com retificações e incorporações de ideias e materiais, com a constante abertura de rumos [...] (2019, p. 213).

Assim, o caráter processual do trabalho - desde sua idealização até todas as leituras que o reencenam a cada momento - se coloca enquanto condição primeira para sua existência. Essa característica processual do livro configura-se um convite em aberto e anula uma direção única para a leitura que contemple todos os textos ali presentes.

$*$

Mirado em panorâmica, persiste a indelével marca de um work in progress, como também é sugerido por Brandão (2019, p. 212); ou seja, um trabalho que não apaga a memória de seu fazer. A mesma memória do processo que Theodor Adorno pontuou quanto ao ensaio, também as artes da cena nos fizeram íntimos. Por certo, o híbrido em que se conforma Canção de amor comunga junto a essas potências, a do ensaio, a da cena. Generoso à sua memória, que não deve ser confundida com lembrança tão somente, o livro é o resíduo que permanece das etapas de sua elaboração, como se cada uma viesse constituir uma estação. Conjunto de textos organizados, sumarizados, mas que não nos deixa perder de vista a sensação de acaso, de imprevisibilidade no gesto de passar/passear pelas suas páginas.

Passeio no qual parece inevitável nos sentirmos ora mais atraídos ao material proposto, ora nem tanto. Digo de uma sedução tipicamente instaurada pela exploração do possível que nos coloca em estado de suspensão quanto aos resultados. Face ao convite em aberto, nosso espírito leitor anseia por ser surpreendido. Nesse sentido, um brevíssimo depoimento parecerá menos ideal do que seu par seguinte, um conjunto de poemas, uma série de registros fotográficos, enfim. De todo, é ainda a 
própria lógica disparadora do ato de abrir o livro que deve contornar esses átimos de preferências. Um modo operacional convite em aberto não pode mesmo conviver com expectativas formais de acabamentos.

Brandão já tangenciava esses procedimentos críticos. Em Teoria do espaço literário, publicado em 2013, já está declarado o tripé de uma investigação a um só tempo teórica, crítica e ficcional - passagens a que denomina como "excurso ficcional". Desdobrar a formalidade da investigação crítica, também segundo "o diapasão literário", representa, assim, a liberdade especulativa se expressando não por meio de conceitos, mas de imagens e cenas (BRANDÃO, 2013, p. 10).

No excurso de nome "Poeta na página", de Teoria do espaço literário, o autor se aninha no espaço mesmo da folha, enquanto materialidade incontornável, à caça do poeta. Fala-nos a seguinte voz que ali se forja: "[...] Há um poeta nesta página e tenho que encontrá-lo depressa, pois o prazo é curto. Implacavelmente só disponho do tempo que esta página durar" (BRANDÃO, 2013, p. 199). O interstício que se realiza entre teoria, crítica e literatura ficcional diz da experiência intelectual que reluta contra o recalque do espaço, do tempo, do suporte de seu fazer-se objeto no mundo. $\mathrm{Se}$ o espaço em que se conforma o texto teórico-crítico é silenciado, pois basicamente é prenhe de uma matéria da qual se ocupa por dever e obrigação de controle, fazer emergir esse mesmo espaço é um movimento escritural que antes de se exibir como forma apoteótica, deixa-se entrever como uma forma em busca de si mesma.

$*$

A função crítica interpelada por Luis Alberto Brandão é também a de um sujeito em busca de uma alteridade que lhe surpreenda ou lhe incite certa fusão amorosa e trágica que se projete ou como acontecimento ou como esquecimento de si mesmo. O crítico, aqui, é o ser que descobre em si e a 
partir de si os sentidos da obra na qual ele precisa, antes de tudo, naufragar, uma vez que todo entroncamento entre obra e crítica pressupõe, também, certa dose de excesso e de fracasso que movimente a elaboração de vias de acesso e de saída, de tradução e de enigma insolúvel.

*

A resenha de Canção de amor versa também sobre a literatura de João Gilberto Noll. Curiosamente, esta parece ser a possibilidade menos óbvia. Claro, há materiais na composição do livro que tipicamente servem para os arquivos autorais, como a entrevista realizada por Pedro Maciel com Noll em 1999. No todo, mira-se a literatura do autor através desse esquema mediado, um entremeio similar àquele de revisão crítica, mas que se permite avançar por espaços mais experimentais à medida que valoriza a premissa fruitiva "ler escrever", enfocando, desfocando.

A partir dessa chave indireta, no entanto, o exercício de ressonância posto em prática parece tocar em alguns pontos vitais de seu elo primeiro, Noll. Nesse sentido, o livro contorna a possível acusação de que não se prestasse a um conhecimento literário a respeito de seu autor, objeto de análise. Isso é observado logo em seu texto inicial: "começo com a impossibilidade de um começo. Começo tentando preservar a força do silêncio, a ele me manter agarrado, como a um pedaço de madeira no mar alto e revolto e instável e perigoso das palavras" (BRANDÃO, 2019, p. 13). Ora, quão vasta é a dúvida do começo, da permanência, é a escuta do silêncio na literatura de João Gilberto? Quão vasto é nela um devir poético encrustado, caça obcecada pelo instante, pela ficção no instante, como também ressoa Canção de amor. E quando a Canção nos conduz em sua toada ao porto das imagens, ou antes, a considerar as nuances de diagramação, a heterotopia da página, trânsito entre cheio e vazio, claro e escuro [...] não estaria também nos conduzindo para a escuta da complexidade narrativa de Noll?

Canção de amor para João Gilberto Noll, por certo, é um movimento híbrido que parece sinalizar ao impasse que nos deixou João Gilberto em sua obra; uma literatura desejante, para a qual a crítica, a esta altura, arriscase acabrunhada, limitada a um mesmo padrão do olhar teórico. Se esta 
resenha, ao questionar sua possibilidade de fala, parece entrar no arco do próprio título resenhado, este, por sua vez, parece despontar no arco dos impasses nolleano.

$*$

Finalmente, parece ser alcançado o desejo de Brandão de que seu "'Livro de amor' soasse infinito", pois, além de tudo, ele lança no campo cultural e literário uma espécie de pergunta-limiar sobre o estatuto da crítica na contemporaneidade, suas fronteiras e seus prolongamentos, iluminando outras possibilidades de aproximação e do autor e de sua obra. Essa proposição de crítica como experimento poético abre vistas a um devir inesgotável, posto que se trata, sobretudo, de transcriação e interpretação ativa e recriadora do arcabouço de imaginários, vozes, fantasias, ruídos, plasticidades e biografemas ${ }^{3}$ que grandes autores mobilizam, como é o caso desse Noll cantado por Brandão et alii em Canção de amor para João Gilberto Noll.

3 Conceito cunhado por Roland Barthes, que propõe a tomada de um aspecto, um detalhe, um evento da vida de um sujeito como metonímia para narrar essa vida. 




perspectivismo: humanos em escala animal (imagem de Juliana Caldas). 


\section{referências}

ADORNO, Theodor W. Notas de literatura I. São Paulo: Duas Cidades; Ed. 34, 2003. (Coleção Espírito crítico).

BARTHES, Roland. Sade, Fourier, Loyola. Trad. de Mário Laranjeira. São Paulo: Brasiliense, 1990.

BRANDÃO, Luis Alberto. Canção de amor para João Gilberto Noll. Belo Horizonte (MG): Relicário, 2019.

Teorias do espaço literário. São Paulo: Perspectiva; Belo Horizonte:

FAPEMIG, 2013. 